\section{INTEGRATED SLOPE STABILITY ANALYSIS (SSA) WITH TRANSIENT GROUNDWATER FINITE ELEMENT METHOD FOR EMBANKMENT ANALYSIS}

\author{
Supandi Sujatono*
}

Department of Mining Engineering, Institut Teknologi Nasional Yogyakarta, Jl. Babarsari, Tambak Bayan, Caturtunggal, Kec. Depok, Kabupaten Sleman, Daerah Istimewa Yogyakarta Yogyakarta, 55281, Indonesia
Article history

Received

13 January 2021

Received in revised form

19 May 2021

Accepted

7 June 2021

Published online

20 August 2021

*Corresponding author supandi@sttnas.ac.id

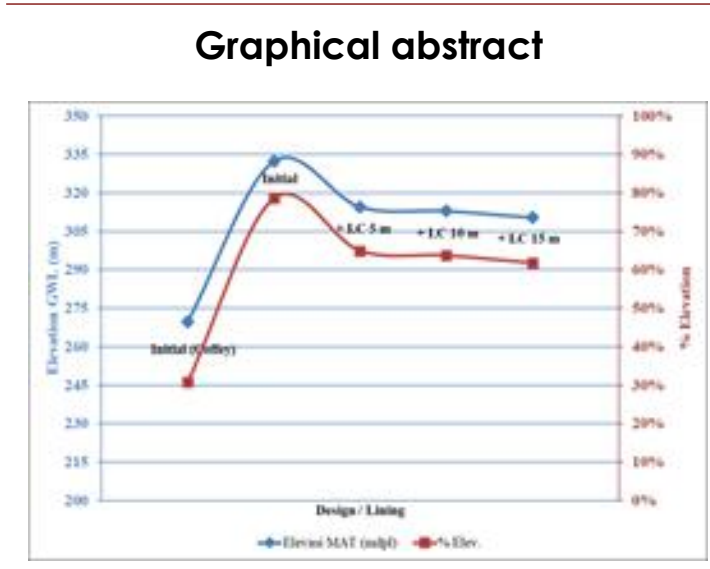

\begin{abstract}
The content of level has a big enough role in the value of the physical characteristic and the mechanical of material. The behavior of water in these materials needs to be analyzed first in order to support the slope stability analysis. Modeling of water behavior in materials in the construction of Tailing Storage Facilities (TSF) will be integrated in the slope stability analysis. This study aims to provide an explanation about the analysis of the Fishing Storage Facilities (TSF) which integrates transient groundwater analysis using the finite element method in supporting the stability analysis of the embankment of Tailing Storage Facilities (TSF). The variables that are used in the analysis, they are the parameters of physical properties and mechanic material for embankment and permeability parameters in analyzing groundwater. The analysis method for geotechnical and geohydrology modeling uses the finite element method. The results of analysis showed that groundwater behavior in the embankment material can be known in detail so that it can be integrated with stability analysis. It can be seen that there is a decrease in the value of the slope safety factor using the Integrated Slope Stability Analysis method compared to the conventional method. Adding an impermeable layer using a thickness of 5 $\mathrm{m}$ of clay material and a thickness of 20-30 $\mathrm{m}$ to support the retaining wall / foot is the criterion of optimal stability. The required lining material thickness (D) can be expressed by the following drawdown percentage equation function: reduction percentage $=(1-0.8661 \mathrm{D}(-0.031)) * 100 \%$. It occurs because the behavior of groundwater can be analyzed according to the real conditions in the field. The accuracy of geotechnical analysis will be improved with this method.
\end{abstract}

Keywords: Dam, embankment, evaluation, facility, hydrogeology, seepage, transient, tailing

\subsection{INTRODUCTION}

Tailing Storage Facility (TSF) dam is one of the largest structures built to accommodate mining residue. Embankments are constructed with a fraction of the tailings [1]. Although there are some similarities to water dams, there are very significant differences. Fundamental differences in the function of the dam itself are represented in the aspects of design objectives, engineering and environmental criteria, construction processes, and operations [2]. Weak zone witth thin layer is appears at the beeding and it is 
usually found a thin layer that can trigger instability of slope. Slope stability of low-wall is affected by bedding contact between two rocks [3]. Bedding contact is usually in the form of clay which has high plasticity, thus it will separate two different beds. Overstress occurs due to difference in bedding ratio between the top and the bottom. The smaller the bedding ratio, the smaller the safety factor produced [4]. Since the rock bedding has a weak zone, it may cause failure at the toe.

TSFs often represent the environmental vulnerability associated with mining operations [5]. The peak period of dam failure occurred in 1960-1980 with an incidence of 50 cases/decade; in the following decades it decreased to 20 cases/decade [6]. TSF reliability is the lowest among other soil structures [7]. Dam failure susceptibility is generally caused by the following factors: (i) dyke construction with residual material from mining operations; (ii) the increasing of the dam sequentially as the effluent water content increases; (iii) lack of regulation in design criteria; (iv) high post-mining maintenance costs [8]. Based on the above factors, the main reason for failure is due to "unusual rain" and bad management [6].

In construction planning, it is necessary to pay attention to environmental safety aspects including the location and distance as far as possible from vital objects such as operational facilities and residences to ensure accidents with severe impacts do not occur. Environmental risks in the disposal process include dam safety, as well as operational issues related to the potential contamination of acid mine drainage. Transparency of the safety and environmental security situation associated with dams need to be ensured to increase awareness and preparedness. Then, mitigate the impacts that can occur to anticipate accidents [9, 10].

In analyzing the slope stability of the Tailing Storage Facility (TSF), one of the main components in it is the hydrogeological parameter. Hydrogeological conditions which include position, behavior, dynamics, and interaction of groundwater with materials which play a major role in embankment stability [1 1-22].

It has long been known that the observed pore pressure data correlates well with several types of dam failures [23]. Hydraulic complexity can have an impact on water flow in the material [24-25]. There are at least 4 main factors that affect the value of hydraulic conductivity such as rock mass, lithology, depth, and material fill (gouge) in the existing hydraulic system [26]. Changes in groundwater level and mixing with the material in a medium can affect the strength of the rock to bear the load [27].

The earliest attempts to apply the finite element method to hydrogeology were made in the mid-1960s and well implemented in the early 1970s. This method is a useful tool in solving the problem of subsurface water flow in a complex scope [28]. Some of the main applications of FEM in subsurface hydrogeology to stress analysis problems operate on systems in equilibrium conditions. Likewise, the use of FEM for underground water flow problems and seepage in steady state. Initial attempts to apply the FEM method to steady-state heat flow, steady state seepage problems on anisotropic and heterogeneous mediums, followed by applications for seepage on the free surface [28].

Estimation on soil behavior parameters and their relationship to conductivity can be obtained from the groundwater characteristics relationship curve in a nonlinear equation. This equation is based on the assumption that the shape of the water characteristic curve depends on the pore size distribution of the soil [29]. In solving problems, a large system is divided into smaller and simpler parts known as finite elements, which are then compiled into a larger system of equations that model all problems [30].

The slope stability analysis carried out previously has not calculated the hydrogeological parameters in the TSF constituent components. The assumption in the analysis is that there is no flow in the embankment, but the flow is in the contact area under the embankment material. The nature of the embankment material which is drier than the saturated tailings, will tend to have a greater conductivity value for similar materials [31]. This allows for potential flow within the embankment. The groundwater level has a strong influence on the water content, pore pressure, and the shear strength of the material [32]. The presence of water in the embankment can react physically (changes in water content) and chemically with the material, especially if there is an unstable clay mineral. This reaction has the potential to reduce the strength of the material [33].

This causes the previous slope stability analysis that has been carried out tends to be dubious. This study was conducted to assess and evaluate the TSF slope stability analysis that had been carried out previously. It is hoped that with a more careful evaluation of hydrogeological conditions, the results of the analysis of slope stability and optimization of the TSF safety factor (FoS) in this study can reflect actual conditions in the field and be more reliable for the basis of decision making.

\subsection{METHODOLOGY}

The study is carried out by analyzing the physical and mechanical parameters of the Tailing Storage Facilities (TSF) constituent components used in the previous slope stability analysis. The geometric parameters and physical criteria of the TSF used in the analysis are shown in Figure 1. The geometric boundaries of the Tailing Storage Facilities (TSF) constituent components are obtained by digitizing directly in the figure. The error tolerance in digitizing the geometry is less than 1 $\mathrm{m}$ for a range of $600 \mathrm{~m}$. Thus, it can be said that the coordinates of the geometric boundaries are likely to be the same or resemble each other. For parameters that are not stated or defined in the previous analysis and the analysis report is determined independently in this study. 
Slope stability analysis in this study was carried out using the Limit Equilibrium Method (LEM) with the Spencer calculation method. The spencer calculation method was chosen because it takes into account the balance of force and momentum in the slice [34]. Hydrogeological parameters were simulated using the Transient Groundwater Finite Element Analysis (T-GFEA) method. This method is very useful in estimating the behavior of complex groundwater flows in the material in a time-dependent manner $[35,36]$.

Slope stability analysis was performed simultaneously with hydrogeological analysis. This is necessary so that the analysis can be carried out comprehensively including aspects of hydrogeology and slope stability embankment; as in some cases of stability analysis of bank slope [37]; stratovolcano flank collapse [38]; earth dam Jatigede [39]; slope embankment koga dam [38]. The criteria in the analysis are defined in order to optimize the safety of the TSF, such as providing an impermeable layer, sloping embankment, and simulating retaining toe as a TSF support component. In this study.

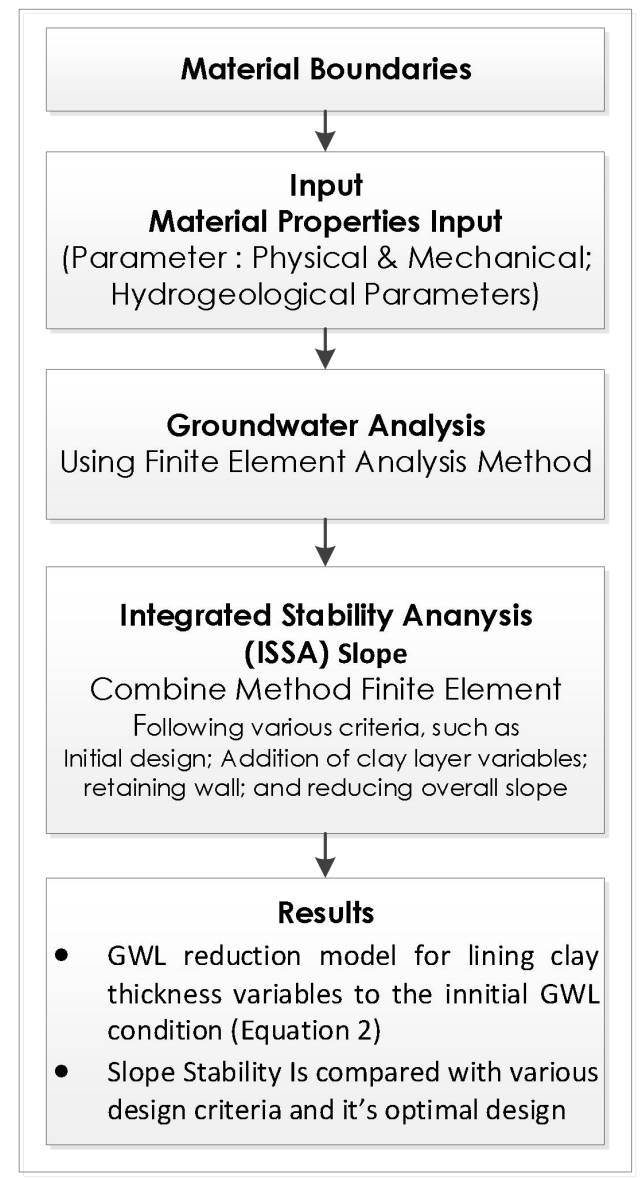

Figure 1 Flow chart of Integrated slope stability analysis method

\subsection{RESULTS AND DISCUSSION}

\subsection{Material Properties}

The physical, mechanical, and hydraulic properties used in the analysis in this study are shown in Table 1. Considering that the material for the tailings dam embankment for TSF is a material that will experience "wetting", it tends to have a greater conductivity value than tailings material which has decreased moisture content (drying) for similar materials [31]. Since the material for the embankment (wetting - solid waste) is assumed to be in a compacted state, the $K$ value is considered the same for the two materials. However, the material model will be determined differently (wetting and drying waste) in the analysis, following the material model according to [31].

Clay material ( $\mathrm{CH}-\mathrm{MH})$ which has a moisture content of $29.6 \%$ Natural water content (NWC) is used as packed pile and basement. The more saturated material with a moisture content of $47.7 \%$ was assumed to be tailings. The tailings material is considered to be oversaturated with respect to stagnant. The tailings material is considered to be oversaturated with respect to stagnant of water. The groundwater level over time will be modeled using the transient groundwater finite element analysis method

\subsection{Underdrainage System Ineffectiveness}

In evaluating the stability of the TSF slope, the underdrainage system in the TSF proved ineffective in the dewatering process of the tailings material. Drainage is blocked due to suspension and colloid particles. Thus, the underdrainage criterion was ignored in the evaluation. Instead, the analysis will simulate a more impermeable layer at the contact boundary between the tailings and the embankment (tailings dam). The material with a lower hydraulic conductivity value than the embankment lining material is expected to inhibit groundwater infiltration, considering that hydraulic conductivity affects the infiltration rate and groundwater seepage [41].

\subsection{Transient Groundwater Finite Element Analysis ( $\mathrm{T}$ - GFEA) Parameters}

The parameters used for the T-GFEA are shown in Table 2. The percentage value of water "recovery" is used as the basis for the assumption of the percent reduction in water content followed by a changing water level due to water flowing from the TSF system at a certain time due to settlement of the material. The "undrained" criterion is defined as the drawdown for the portion of the tailings away from the embankment. Meanwhile, the "drained" criterion is determined for the part of the tailings that is close to the embankment (beach), simulating drying by sunlight and seepage of water through the embankment. This criterion is mentioned in the reports for the tailing settlement and drying tests, but was not used in the previous analysis. 
Table 1 Material properties

\begin{tabular}{|c|c|c|c|c|c|c|c|c|c|}
\hline \multirow[b]{2}{*}{ Material Type } & & \multirow[b]{2}{*}{$\begin{array}{l}\text { Bulk } \\
\text { Density } \\
\left(\mathrm{kN} / \mathrm{m}^{3}\right)\end{array}$} & \multicolumn{3}{|c|}{ Effective Strength Parameter } & \multirow[b]{2}{*}{$\mathrm{Ea}^{* *}(\mathrm{kPa})$} & \multirow[b]{2}{*}{$\begin{array}{l}\text { Poisson's } \\
\text { Ratio** }\end{array}$} & \multirow[b]{2}{*}{$\begin{array}{l}\text { Hidraulic } \\
\text { Conductivity } \\
(\mathrm{m} / \mathrm{s})\end{array}$} & \multirow[b]{2}{*}{ Note } \\
\hline & & & $\begin{array}{l}\text { Cohesion } \\
c^{\prime}(\mathrm{kPa})\end{array}$ & $\begin{array}{l}\text { Friction } \\
\text { Angle } \quad \varphi^{\prime} \\
\text { (degrees) }\end{array}$ & $\begin{array}{l}\text { Tensil } \\
\text { Strength } \\
(\mathrm{kPa})^{* *}\end{array}$ & & & & \\
\hline $\begin{array}{l}\text { Deposited } \\
\text { (Drying) }\end{array}$ & Tailings & 18 & 0 & 25 & 0.00 & 3844.49 & 0.200 & $10^{-7}$ & $\begin{array}{l}\text { Upper } \\
\text { bound }\end{array}$ \\
\hline $\begin{array}{l}\text { Compacted } \\
\text { Mine Waste }\end{array}$ & Clayey & 20 & 5 & 25 & 10.72 & 5200.78 & 0.224 & $10^{-7}$ & Wetting \\
\hline Waste & & 22 & 0 & 38 & 0.00 & 66429.35 & 0.224 & $10-7$ & Drying \\
\hline $\begin{array}{l}\text { Foundation } \\
(\mathrm{CH})\end{array}$ & Clay & 17 & 5 & 30 & 8.66 & 6093.24 & 0.224 & $5 \times 10^{-8}$ & $\begin{array}{l}\text { lower } \\
\text { bound }\end{array}$ \\
\hline Foundation & & 20 & 200 & 30 & 346.41 & 10679.91 & 0.224 & $5 \times 10^{-8}$ & $\begin{array}{l}\text { lower } \\
\text { bound }\end{array}$ \\
\hline
\end{tabular}

Table 2 Parameters used for T-GFEA analysis

\begin{tabular}{|c|c|c|c|c|c|c|c|}
\hline \multirow{2}{*}{$\begin{array}{l}\text { Initial Total } \\
\text { Head }\left(t_{0}\right)\end{array}$} & \multirow{2}{*}{$\begin{array}{l}\text { Range } \\
\text { from Dam } \\
\text { (m) }\end{array}$} & \multirow[t]{2}{*}{ Drainage } & \multicolumn{2}{|l|}{ Settling } & \multirow[t]{2}{*}{$\begin{array}{l}\text { Drawdown } \\
(\mathrm{m}) \mathrm{t}_{\mathrm{n}}\end{array}$} & \multirow{2}{*}{$\begin{array}{l}\text { Total } \\
\text { head } \\
@ t_{n}(m)\end{array}$} & \multirow[t]{2}{*}{ Remarks } \\
\hline & & & Time - $t_{n}$ (day) & Water Recovery & & & \\
\hline \multirow{2}{*}{360.48} & 227.932 & Undrained & 15 & $25.40 \%$ & 20.744 & 339.736 & $\begin{array}{l}\text { Simulating middle part / } \\
\text { far-side from dam }\end{array}$ \\
\hline & 100.000 & Drained & 18 & $12.50 \%$ & 6.693 & 353.787 & $\begin{array}{l}\text { Simulating "Beach" part, } \\
\text { near-dam }\end{array}$ \\
\hline
\end{tabular}

\subsection{Analysis}

The analysis carried out in this evaluation study consists of several stages and criteria as follows:

\subsubsection{Transient Groundwater Finite Element Analysis (T-GFEA)}

Transient Groundwater Finite Element Analysis (T-GFEA) with Slope Stability Analysis (SSA). Up to time (tn) 6 months or 180 days.

\subsubsection{Hydrogeological Management Efforts}

Simulation of a layer of clay material which is more impermeable to the contact between the embankment and the tailings. The thicknesses applied were $5 \mathrm{~m} \mathrm{(+LC} \mathrm{5),} 10 \mathrm{~m}(+\mathrm{LC} 10)$, and $15 \mathrm{~m} \mathrm{(+LC} \mathrm{15),}$ with hydraulic conductivity values of $10-13 \mathrm{~m} / \mathrm{s}$.

\subsubsection{Stabilization Efforts Including}

Efforts to apply retaining wall / toe with vertical thickness or height of $20 \mathrm{~m}$ and $30 \mathrm{~m}$. This criterion targets groundwater flow at the end of the embankment. In addition, a reduction of the slope (10) was also carried out from 140 to 130.

Figure 2 shows the analysis of the previous (initial) slope stability with the predetermined GW. It appears that the condition of the tailings material in the previous analysis is a saturated condition, but the condition of the groundwater table to the embankment is simulated to be under the gray embankment material (mine waste) on contact with the compacted mine waste. 


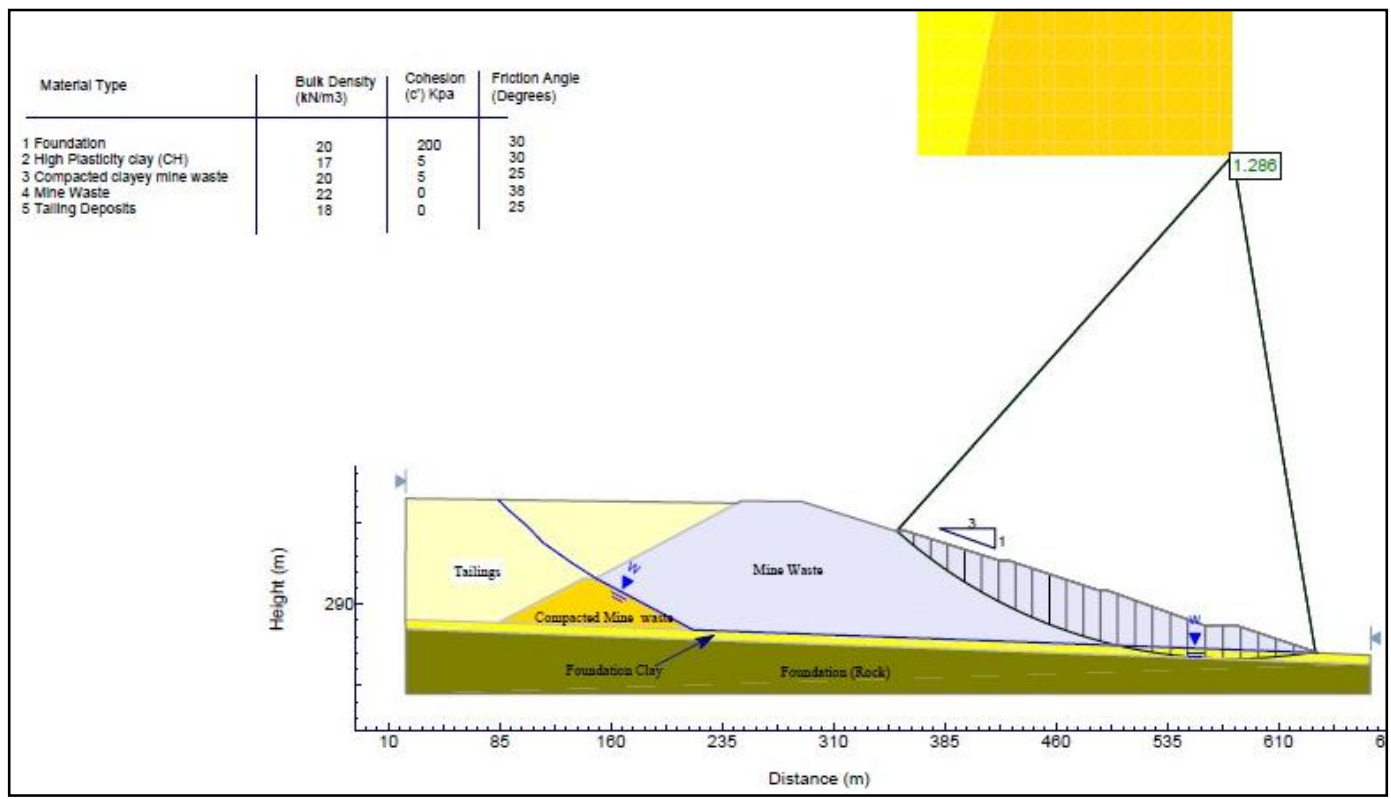

Figure 2 The criteria used as the basis for evaluating the previous analysis

Figure 3 is an example of the results of slope stability analysis using hydrogeological parameters obtained by the transient groundwater finite element analysis method at (tn) 6 months or 180 days. The flow pattern is shown by the flow vector and the groundwater level flowing through the embankment. The difference in position can be observed in the two sections. The groundwater level condition in the initial analysis (predetermined GW) in Figure 2 is much lower than in Figure 3. The pore pressure distribution is getting closer to 0 at a position closer to the groundwater level. The higher the ground water level in a material, the pore pressure due to the ground water level will be greater at a point of the same height in the material.

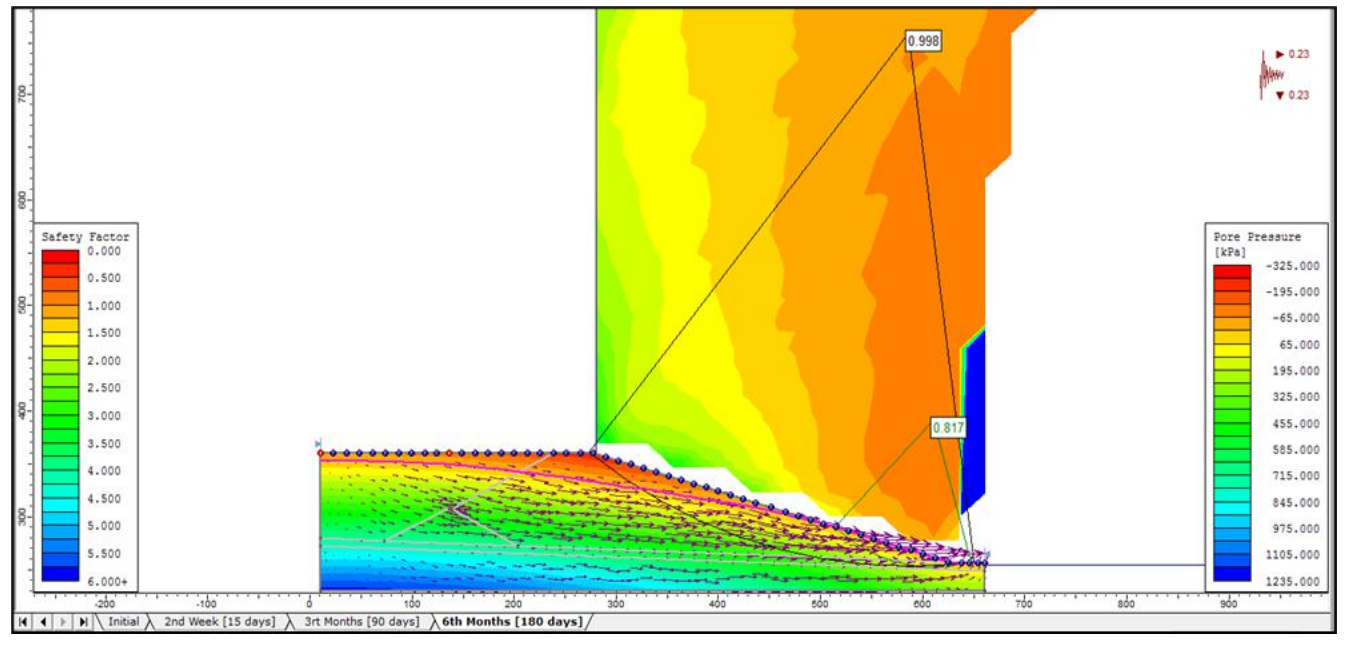

Figure 3 Slope stability analysis with T-GFEA, tn 180 days

The rate of subsidence in the groundwater table reflects the natural settlement and consolidation processes that occur in the material body. This parameter refers to the laboratory test mentioned in the previous report. The groundwater distribution analysis in Figure 2 seems to ignore the conductivity of the embankment, or seems impermeable. Compared to previous analysis reports, the groundwater level tends to be higher due to water flow in the embankment. Thus, the total head pressure and pore pressure increase which can lead to destabilization of the embankment.

The difference in hydrogeological parameters between the previous analysis and the analysis in this study is very significant which has an impact on Fos obtained from the results of the slope stability analysis. The previous analysis resulted in a Fos of 1.286 while the analysis in this study obtained a FoS of 0.998 for an 
overall slope of 140 for an embankment height of about $103.4 \mathrm{~m}$. It should be noted that there is a smaller Fos value in the toe of the embankment, which is 0.818. This occurs due to the saturation of the groundwater level in that section.

The simplest effort for stabilization is to reduce the steepness of the slope which reduces the load on the slope. Simple reinforcement by providing a retaining wall / toe at the toe of the embankment at the level of the groundwater that comes out on the surface is also possible. Basically, these methods are carried out to withstand the existing stress by increasing the resistance force. Other measures can be made to reduce the influence of water or groundwater levels on the embankment body. Actually, the most effective way is to remove water from the inside with a drainage system as a depressurization effort. However, based on previous studies underdrainage systems or similar systems will not work efficiently. Efforts by applying more impermeable materials can be carried out as an effort to manage hydrogeological parameters, in this case groundwater originating from tailings. The next part of the analysis and submission will be presented at a time of th 6 months ( 180 days).

Various hydrogeological conditions were simulated by applying an impermeable material to the contact between the embankment and the tailings. Water is simulated flowing through the contact area between the basement and the embankment. The more impermeable material forces the water flow to move through the weak area (contact zone) so that filling into the embankment body can be reduced. Table 3 contains a summary of the groundwater level parameters with a variety of effort criteria for hydrogeological management from the results of the T-GFEA analysis.

The depth of the MAT listed in the table is measured vertically from the crest embankment. The elevation percentage value is calculated based on the division of the MAT elevation (MAT-base model design elevation) to the vertical range of the model (crest-base model design elevation).

Table 3 Summary of groundwater level data at initial conditions and during application of a more impermeable material

\begin{tabular}{|c|c|c|c|c|c|c|c|}
\hline $\begin{array}{l}\text { Crest } \\
\text { Elevation }\end{array}$ & $\begin{array}{l}\text { Base Model } \\
\text { Design }\end{array}$ & Criteria & Depth GWL & $\begin{array}{l}\text { Elevation } \\
\text { GWL (m.dpl) }\end{array}$ & \% Elev. & GWL MAT & \% Draw Down \\
\hline \multirow{5}{*}{360.5} & \multirow{5}{*}{229.45} & $\begin{array}{l}\text { Initial (Predetermined } \\
\text { GW) }\end{array}$ & 90.76 & 269.74 & $30.74 \%$ & - & - \\
\hline & & Initial (GFEA) & 28.155 & 332.345 & $78.52 \%$ & $100.00 \%$ & $0.00 \%$ \\
\hline & & $+\mathrm{LC} 5 \mathrm{~m}$ & 45.959 & 314.541 & $64.93 \%$ & $82.70 \%$ & $17.30 \%$ \\
\hline & & $+\mathrm{LC} 10 \mathrm{~m}$ & 47.51 & 312.99 & $63.75 \%$ & $81.19 \%$ & $18.81 \%$ \\
\hline & & $+\mathrm{LC} 15 \mathrm{~m}$ & 50.105 & 310.395 & $61.77 \%$ & $78.67 \%$ & $21.33 \%$ \\
\hline
\end{tabular}

Figure 4 shows a visualization of the variation in groundwater level and elevation percent of the MAT against various predetermined criteria. There is a significant difference between the initial conditions used in the previous analysis and the analysis in this study.

The MAT ratio is the ratio at the initial position of this study. MAT that is below the initial MAT has a smaller ratio. The percentage reduction (\%) is calculated by the equation $(\%$ decrease $=(1-\mathrm{MAT}$ ratio) * 100). This value is calculated based on the MAT ratio when the clay lining material is applied to the initial MAT (without lining).
Plotting the percentage value of the MAT ratio against the lining thickness criterion of the clay material (D) with a conductivity value of 10-13 is shown in Figure 5. From the plotting, an equation with a coefficient of determination (R2) of $R^{2}=0.9943$ can be obtained, namely:

$$
\text { MAT Ratio }=\left(0.8661 D^{(-0.031)}\right) * 100 \%
$$

The percentage reduction is the reduction from the ratio of $100 \%$ (initial) to a certain MAT ratio. The equation is as follows:

$$
\text { \%reduction }=\left(1-0.8661 \mathrm{D}^{(-0.031)) * 100 \%}\right.
$$




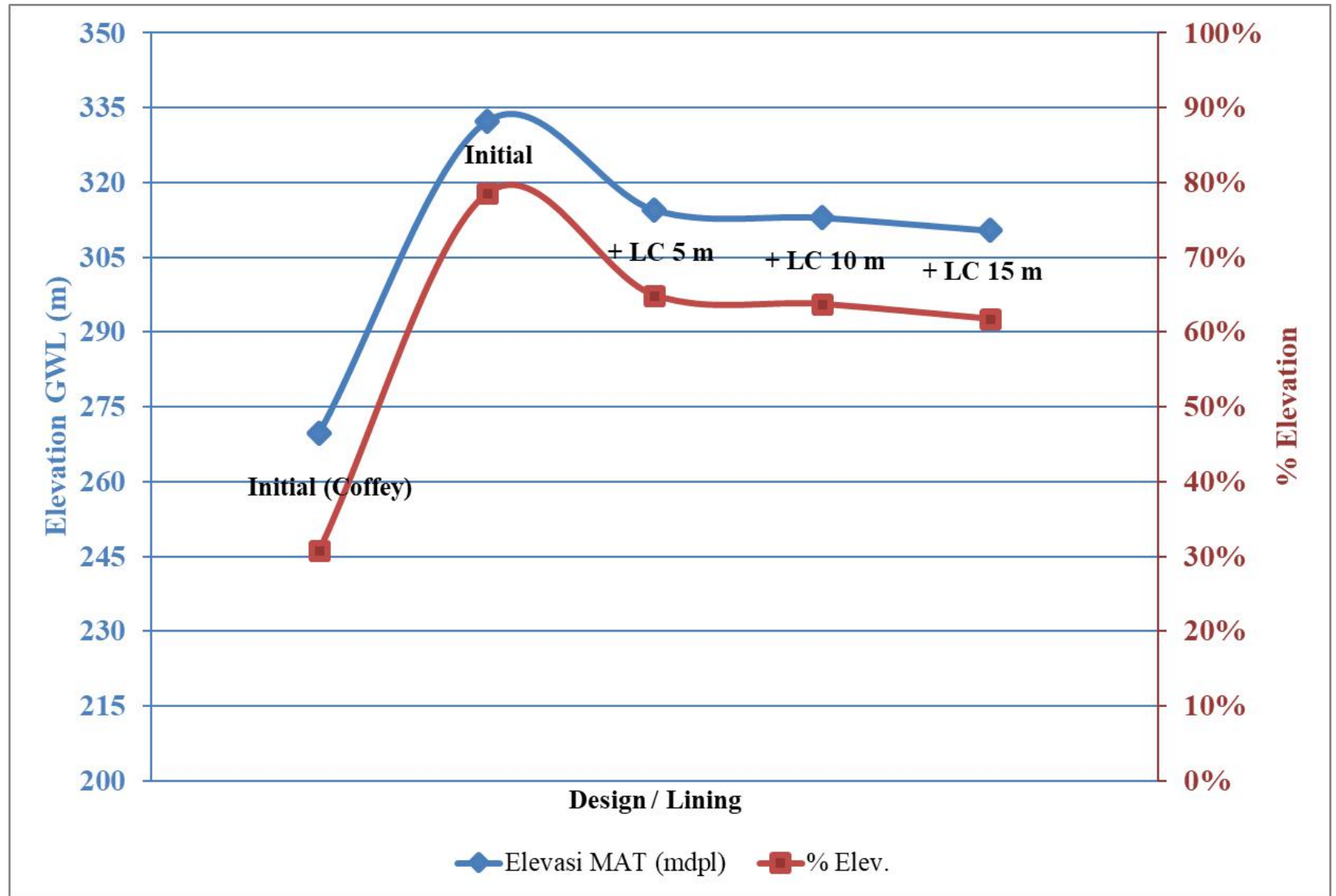

Figure 4 Visualization of variations in the Mat with different design criteria

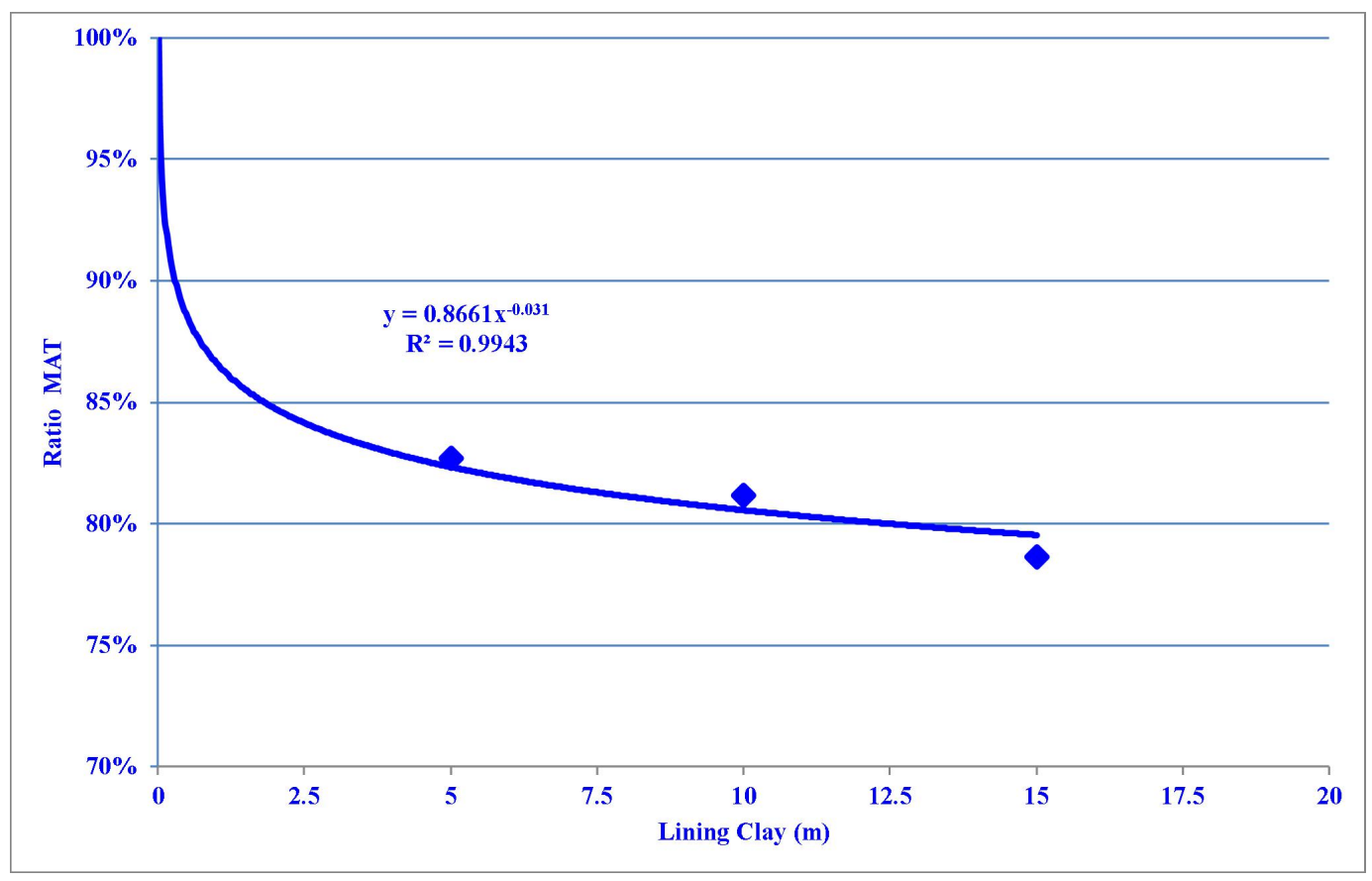

Figure 5 Visualization of variations in the Mat with different design criteria 
This value from the function above is analytical, based on the input parameters used in the analysis mentioned above. Thus, differences with actual conditions in the field can still occur. However, if the characteristics in the field resemble the criteria in the analysis, then the above functions can be used as references in planning and evaluation in monitoring hydrogeological conditions.

The analysis for the stabilization and optimization of the TSF embankment (tailing dam) was carried out with the criteria and results as listed in Table 4. Slope stability analysis was carried out simultaneously with TGFEA analysis with Rocscience software: Slide 6.0. Embankment stabilization cannot only be done by tapping the slopes or adding retaining walls / toe, but requires a combination with control of the ground water level in the embankment body. This statement is also shown in the analysis results in the following table.

Table 4 Summary of the results of embankment stabilization and optimization analysis

\begin{tabular}{|c|c|c|c|c|c|c|}
\hline \multirow{2}{*}{$\begin{array}{l}\text { Stage } \\
\text { Time - } t_{n} \text { (day) }\end{array}$} & \multirow{2}{*}{ Criteria } & & \multirow{2}{*}{$\begin{array}{l}\text { K. Lining } \\
\text { Material }(\mathrm{m} / \mathrm{s})\end{array}$} & \multicolumn{2}{|c|}{ FoS } & \multirow{2}{*}{ Remarks } \\
\hline & & & & Overall & Toe & \\
\hline \multirow{9}{*}{$6^{\text {th }}$ Month 180} & Initial Design & & & 0.998 & 0.818 & Unstable \\
\hline & Lining $5 \mathrm{~m}$ Clay & & $K=10^{-13}$ & 1.146 & 0.849 & Toe Unstable \\
\hline & Lining $10 \mathrm{~m}$ Clay & & $K=10^{-13}$ & 1.159 & 0.858 & Toe Unstable \\
\hline & Lining 15 m Clay & & $K=10^{-13}$ & 1.161 & 0.865 & Toe Unstable \\
\hline & Lining $5 \mathrm{~m}$ Clay & slope embankment $14^{\circ}-->13^{\circ}$ & & 1.209 & 0.886 & Toe Unstable \\
\hline & Initial Design & retaining wall / toe $20 \mathrm{~m}$ & & 1.183 & 0.900 & Toe Unstable \\
\hline & Initial Design & retaining wall / toe $30 \mathrm{~m}$ & & 1.276 & 1.005 & Toe Critical \\
\hline & Lining 5 m Clay & retaining wall / toe $20 \mathrm{~m}$ & $K=10^{-13}$ & 1.255 & 1.140 & Stable \\
\hline & Lining $5 \mathrm{~m}$ Clay & retaining wall / toe $30 \mathrm{~m}$ & $K=10^{-13}$ & $1.396 / \mathrm{Glc}$ & bal min.) & Stable \\
\hline
\end{tabular}

\subsection{CONCLUSIONS}

The underdrainage system in the TSF will be ineffective in the dewatering process of the tailings material. Efforts are needed to manage the hydrogeological parameters related to the groundwater level in the embankment material. In general, the above functions apply to TSF constituent clay components with a hydraulic conductivity of 10$7 \mathrm{~m} / \mathrm{s}$, and lining materials with a hydraulic conductivity of $10^{-13} \mathrm{~m} / \mathrm{s}$. The function of the drawdown percentage equation for the required lining material thickness (D) is as follows:

$$
\% \text { reduction }=\left(1-0.8661 D^{(-0.031)}\right) * 100 \%
$$

The optimum stability criterion is to add a more impermeable lining of the clay material to a thickness of $5 \mathrm{~m}$ and to support the retaining wall / toe with a thickness of $20-30 \mathrm{~m}$.

\section{Acknowledgments}

Acknowledgements are addressed to PT. AB Omah Geo for all the support given to the author in conducting this research.

\section{References}

[1] Vick, S. 1983. Planning, Design, and Analysis of Tailings Dams. New York: John Wiley \& Sons.
[2] Benckert, A., Eurenius, J. 2001. Tailings Dam Construction. Seminar on Safe Tailings Dams Constructions. 19-25.

[3] Supandi and Hidayat, H. 2013. The Impact of Geometry Bedding Toward Slope Stability in Coal Mining. Proceedings of the Fourth International Symposium of Geotechnical Safety and Risk. Hong Kong, China. 559-562.

[4] Supandi. 2014. Determination Material Properties on Bedding Contact at the Low-wall Part of Coal Mine. Proceedings of International Society for Rock Mechanics and Rock Engineering EUROCK. Vigo, Spain. 229-233

[5] Martin, T., Davis, M. 2011. Trends in the Stewardships of Tailing Dams. Fonte: http://library/publicationsweb.archive.org/web/20131126 070721/http://www.infomine.com/

[6] Azam, S., Li, Q. 2010. Tailings Dam Failures: A Review of the Last One Hundred Yeras. Geotechnical News. 50-53.

[7] Morgenstern, N. R. 2001. Geotechnic and Mine Waste Management - Update. Seminar on Safe Tailings Dams Constructions. 43-56.

[8] Rico, M., Benito, G., Salgueiro, A. D.-h., Pereira, H. 2007. Reported Tailings Dam Failures: A Review of the European Incidents in the Worldwide Context. Netherland: Elsevier.

[9] Mill, O. 2001. Safe Tailings Dam Construction. Seminar on Safe Tailings Dams Constructions. 1-9.

[10] Bundesanstalt für Wasserbau. 2011. Stability of Embankments at German Inland Waterways (MSD). Karlsruhe. Germany: Bundesanstalt für Wasserbau (BAW).

[11] Jiao, J. J. 2000. A Confined Groundwater Zone in Weathered Igneous Rocks and Its Impact on Slope Stability. International Symposium on Hydrogeology and the Environment. Wuhan, China. 1-8.

[12] Soddu, S., Delitala, G., Sciabica, M., Barrocu, G. 2003. Modelling Groundwater Effects on Slope Stability. RMZ Materials and Geoenvirontments. 50(1): 349-352.

[13] Brehaut, R. J. 2009. Groundwater, Pore Pressure and Wall Slope Stability - A Model for Quantifying Pore Pressures in Current and Future Mines. Christchucrch, New Zealand: University of Canterbury.

[14] Cascini, L., Calvello, M., Grimaldi, G. M. 2010. Groundwater Modeling for the Analysis of Active Slow- 
Moving Landslides. J. Geotech. Geoenviron. Eng. 136: 1220-1230. DOI: https://doi.org/10.1061/(ASCE)GT.19435606.0000323 .

[15] Crosta, G., Prisco, C. d., Frattini, P., Frigerio, G., Castellanza, R., Agliardi, F. 2013. Chasing a Complete Understanding of the Triggering Mechanisms of a Large Rapidly Evolving Rockslide. Landslides. 1-18. DOI: https://doi.org/10.1007/s10346-013-0433-1.

[16] Acharya, K. P., Bhandary, N. P., Dahal, R. K., Yatabe, R. 2014. Seepage and Slope Stability Modelling of Rainfall Induced Slope Failures in Topographic Hollows. Geomatics, Natural Hazards and Risk. 7(2): 721-746. DOl: https://doi.org/10.1080/19475705.2014.954150.

[17] Johansson, J. M. 2014. Impact of Water-Level Variations on Slope Stability. Department of Civil, Environmental and Natural Resources Engineering, Division of Mining and Geotechnical Engineering. Luleå University of Technology.

[18] Liu, Q., Li, J. 2015. Effects of Water Seepage on the Stability of Soil-slopes. Procedia IUTAM. 17: 29-39. DOI: https://doi.org/10.1016/j.piutam.2015.06.006.

[19] Dassanayake, A., Phien-wej, N., Giao, P. H. 2016. Groundwater Flow Modeling and Slope Stability Analysis for Deepening of Mae Moh Open Pit Lignite Mine. Geotechnical Engineering Journal of the SEAGS \& AGSSEA. 47(3): 101-115.

[20] Kukemilks, K., Wagner, J., Saks, T., Brunner, P. 2018. Physically based Hydrogeological and Slope Stability Modeling of the Turaida Castle Mound. Landslides. 15(11): 2267-2278. DOI: https://doi.org/10.1007/s 10346-018-1038-5.

[21] Frans, J. S., Nurfalaq, M. H. 2019. Studi Geoteknik Pengeruh Muka Air Tanah Terhadap Kestabilan Lereng Tambang Batubara. Indonesian Mining Professionals Journal. 12-21. DOI: https://doi.org/10.36986/impj.v1il.7.

[22] Latief, R. H., Zainal, A. K. 2019. Effects of Water Table Level on Slope Stability and Construction Cost of Highway Embankment. Engineering Journal. 23(5): 1-12. DOl: https://doi.org/10.4186/ej.2019.23.5.1.

[23] Peck, R. 1969. Advantages and Limitations of the Observational Method in Applied Soil Mechanics. Geotechnique. 19(1): 171-187. DOl: https://doi.org/10.1680/geot.1969.19.2.171.

[24] Cahyadi, T. A., Widodo, L. E., Syihab, Z., Notosiswoyo, S. Widijanto, E. 2017. Hydraulic Conductivity Modeling of Fractured Rock at Grasberg Surface Mine, PapuaIndonesia. J. Eng. Technol. Sci. 49(1): 37-56. DOI: https://doi.org/10.5614/j.eng.technol.sci.2017.49.1.3.

[25] Supandi, 2021. Determination of Mine Waste Dump Material Properties Through Back Analysis. King Saud University Journal. 234-234. https://doi.org/10.1016/j.jksues.2021.02.008.

[26] Supandi, S., Riyadi, F. A., Purnomo, S. 2016. Resistivity Study to Identify Mud Pond at the Inpit Dump, (original paper in Bahasa). 202: 352-356. https://journal.itny.ac.id/index.php/ReTll/article/view/202.

[27] Narasimhan, T., Witherspoon, P. 1982. Overview of the Finite Element Method in Groundwater Hydrology Berkeley, California USA. In: K. P. al., Finite Elements in Water Resources (K. P. Holz et al. (eds.). 129-130. SpringerVerlag Berlin Heidelberg. DOI: https://doi.org/10.1007/9783-662-02348-8_2.

[28] Fredlund, D., Xing, A. 1994. Equations for the Soil-water Characteristic Curve. Can. Geotecli. J. 31: 521-532. DOI: https://doi.org/10.1139/t94-061.

[29] Logan, D. L. 2011. A First Course in the Finite Element Method. Cengage Learning.

[30] Leong, E. C., Rahardjo, H. 1997. Permeability Function for Unsaturated Soil. J. Geotech. Geoenviron. Eng. 123(12): 1118-1126. DOI: https://doi.org/10.1061/(ASCE)10900241 (1997).

[31] Supandi, Zakaria Zufialdi, Sukiyah Emi, Sudradjat Adjat. 2018. The Correlation of Exposure Time and Claystone Properties at the Warukin Formation Indonesia. International Journal of GEOMATE. 15(52): 160-167. Https://10.21660/2018.52.68175.
[32] Supandi, Zakaria Zufialdi, Sukiyah Emi, Sudradjat Adjat. 2019. The Influence of Kaolinite-Illite Toward Mechanical Properties of Claystone. Open Geosciences. 11(1): 440446. Https://10.1515/geo-2019-0035.

[33] Abramson, L., Lee, T., Sharma, S., Boyce, G. 2001. Slope Stability and Stabilization Methods. 2nd edition. John Wiley \& Sons.

[34] Agyei, E. O. 1997. Groundwater Modelling and Management using the Finite Element Method and Evolutionary Optimization Technique. Adelaide: University of Adelaide.

[35] Gofar, N., Lee, L. M., Asof, M. 2006. Transient Seepage and Slope Stability Analysis for Rainfall-Induced Landslide: A Case Study. Malaysian Journal of Civil Engineering. 18(1): $1-13$.

[36] Liu, X., Zhang, Z. 2010. Stability of Bank Slope Under Reservoir Water Drawdown. 2010 International Symposium on Multi-field Coupling Theory of Rock and Soil Media and It's Applications. 533-537.

[37] Ball, J. L., Taron, J., Reid, M. E., Hurwitz, S., Finn, C. Bedrosian, P. 2018. Combining Multiphase Groundwater Flow and Slope Stability Models to Assess Stratovolcano Flank Collapse in the Cascade Range. Journal of Geophysical Research: Solid Earth. 123: 2787-2805. DOI: https://doi.org/10.1002/2017JB015156.

[38] Minmahddun, A., Fathani, T. F., Faris, F. 2018. Determination of Stability During First Impounding in Jatigede Earth Dam. Journal of Applied Geology. 3(2): 5261. DOI: https://doi.org/10.22146/jag.48592.

[39] Zewdu, A. 2020. Modelling of Slope of the Embankment Dan during Static and Dynamic Stability Analysis: A Case Study of Koga Dam, Ethiopia. Modelling Earth System an Environtment. 6. DOI: https://doi.org/10.1007/s40808-02000832-8.

[40] Yeh, H.-F., Tsai, Y.-J. 2018. Analyzing the Effect of Soil Hydraulic Conductivity Anisotropy on Slope Stability Using a Coupled Hydromechanical Framework. Water. 10: 905. DOI: https://doi.org/10.3390/w10070905.

[41] Bouwer, H., \& Rice, R. C. 1976. A Slug Test for Determining Hydraulic Conductivity of Unconfined Aquifers with Completely or Partially Penetrating Wells. Water Resource Research. 12(3): 423-428.

[42] Singh, P. 2009. Major, Trace and REE Geochemistry of the Ganga River Sediments: Influence of Provenance and Sedimentary Processes. Chemical Geology. 266(3-4): 242255.

[43] Supandi and Hartono H. G. 2020. Geomechanic Properties and Provenance Analysis of Quartz Sandstone from The Warukin Formation. International Journal of GEOMATE. 18(66): https://10.21660/2020.66.50081

[44] Supandi, Zakaria Z., Sukiyah E. and Sudradjat A. 2020. New Constants of Fracture Angle on Quartz Sandstone. International Journal on Advanced Science Engineering and Information Technology. 10(4): 1597-1603. Https://10.18517/ijaseit.10.4.8272.

[45] Tao, Y.-z. and Xi, D.-y. 2006. Rule of Transient Phreatic Flow Subjected to Vertical and Horizontal Seepage. Applied Mathematics and Mechanics. 27(1): 59-65. Https://10.1007/s 10483-006-0108-1.

[46] Rahmannejad, R., \& Toufigh, V. 2018. Influence of Curing Time and Water Content on Unconfined Compressive Strength of Sand Stabilized Using Epoxy Resin. International Journal of Engineering Transactions B: Applications. 31 (8): 1187-1195.

[47] Mousavi, S. 2016. Effect of Moisture Content on Shear Strenght of Offshore Clay Interface Steel Surface. International Journal of Engineering Transactions B: Applications. 29(2): 183-191.

[48] Hamedi, A., \& Marundi, S. M. 2011. Laboratory Studies on the Effect of Vertical Gravel Column Drains on Liquefaction Potential. International Journal of Engineering Transactions B: Applications. 24(3): 209-224. 